\title{
Degradation of Synthetic Azo Dyes of Textile Industry: a Sustainable Approach Using Microbial Enzymes
}

\author{
Shrabana Sarkar ${ }^{1}$ Aparna Banerjee ${ }^{1}$ - Urmi Halder ${ }^{1} \cdot$ Raju Biswas $^{1}$. \\ Rajib Bandopadhyay ${ }^{1}$
}

Received: 8 April 2017 /Revised: 28 July 2017 / Accepted: 1 September 2017 /Published online: 18 September 2017

(C) Springer Nature Singapore Pte Ltd. 2017

\begin{abstract}
By releasing of azo dye through textile effluent, textile industry is the main cause of water pollution resulting into acute effect on environment and human health. Development of any eco-friendly and cost-effective method that may address the drawbacks to physical or chemical methods of dye removal is the recent global priority. Physical or chemical methods for textile wastewater pretreatment are of high cost, extremely energy consuming, and environmentally low efficient and generate toxic sludge. Thus, the use of microbial technique for textile dye degradation will be eco-friendly and is probably a lucrative alternative to physico-chemical processes. Microbial enzymes, viz. laccase and azoreductase, are cost-efficient, easy to harvest, easily downstream processable, and effortlessly mobilizable. Recent research trends on nanoparticle-microbial enzyme conjugates are also highly efficient to remove the azo dye from textile waste within a few minutes. But unfortunately, due to some gap between academia and industry, these methods remain only limited up to laboratory and its industrialization is still a challenge. The present review is an illustrated compilation of the use of microbial enzymes in removal of textile dyes.
\end{abstract}

Keywords Textile industry $\cdot$ Synthetic azo dye $\cdot$ Microbial enzyme $\cdot$ Dye degradation

Rajib Bandopadhyay

rajibindia@gmail.com

1 UGC-CAS, Department of Botany, The University of Burdwan, Golapbag, Bardhaman, West Bengal 713104, India

\section{Introduction}

Textile industry captures a principal economic part of India being the oldest industry dating back several centuries. Even today, it is the second largest employer just after agriculture contributing around $11 \%$ of total Indian exports. Indian textile industry, currently estimated at around US $\$ 108$ billion, is expected to reach US\$223 billion by 2021 (http://www.ibef.org/ industry/textiles.aspx; Accessed: 26.07.2017). Development of a textile industry directly contributes to economic growth of any country [1]. Current global apparel market is of worth US\$1.7 trillion. EU, the USA, and China are the world's largest apparel market. According to Global Industry Analysts, Inc. (GIA), the global market for textile machinery is estimated to reach US\$2209 billion in 2017. The global textile and apparel trade is expected to reach at a level of US $\$ 1600$ billion in 2025. EU and the USA are the largest textile markets with a share of 36 and $14 \%$, respectively. On the supply side, China is the largest in the world with a share of $40 \%$, distantly followed by India, Italy, Germany, etc. According to some recent reports, China is going high in both textile machineries and products. Though textile industry bears an important role to the economy of any country, still, this is an environmental impediment. According to the World Health Organization (WHO), $17 \sim 20 \%$ of the industrial water pollution is caused by the dying treatment of textile industry. It had been estimated that in textile industry, about $80 \%$ of azo dyes are used in dying purpose [2], of which approximately $10-15 \%$ of the dyes are lost through effluent into environment without binding to the fiber [3]. A textile that released colored effluents contains toxic materials including reactive dyes, synthetic azo dyes, and many other hazardous chemicals which cause water pollution, loss of the environmental balance, and increase in chemical oxygen demand (COD) and biological oxygen 
demand (BOD) of water by altering $\mathrm{pH}$ and changing organicinorganic chemical content of the water body. This colored waste causes acute toxic effect to the aquatic ecosystem due to low light penetration and oxygen consumption [4]. As every ecosystem is interconnected, thus, the overall integrity of biosphere becomes disturbed, having an unpredictable effect on health. For example, metanil yellow, an azo dye, shows hepatotoxic effects in albino rats $[5,6]$. Synthetic azo dyes are recalcitrant and carcinogenic in nature for presence of $-\mathrm{N}=\mathrm{N}-$ bond [7]. It mainly consists of complex aromatic molecular structure which is almost non-biodegradable. Some chemical and physical processes such as reverse osmosis, coagulation, flocculation, ion exchange, activated carbon adsorption, advanced oxidation, ozonation, photocatalysis, Fenton process, photo-Fenton, electrochemical oxidation [8], and filtration [5] have been used to degrade azo dye from colored textile waste (Fig. 1). But as these processes are much expensive and generate amine residues containing sludge after degradation, regular consumption of such untreated or poorly treated toxic waters shows carcinogenesis in human.

Biological treatment of textile wastewater varies widely ranging from bacterial culture, or fungal culture (Armillaria sp. F022) [5] or by yeast [7] to any consortia. As enzymes have catalytic activity to increase the reaction rate, thus, it may be used even in very minute quantity. So microorganisms that produced enzymes may be used in alleviating the water pollution as a potent alternative. Bacteria are able to degrade azo dye up to a significant level in anaerobic and aerobic conditions consecutively. Anaerobes or facultative anaerobes both give good result in degradation. Bacterial enzymes, viz. azoreductase, laccase, and peroxidase, are able to degrade azo dye in promising percentages. Our present review focuses on microbial enzyme-mediated degradation of azo dyes from textile industry water wastes. A detail mechanism of two enzymes, i.e., azoreductase and laccase, in dye degradation and decolorization process is considered as these two have showed great potential to decolorize extensive range of known industrial dyes. Recent patenting trends of these enzymes are also elucidated in this review.

\section{Chemistry of Azo Dye}

Dyes are the colored substance that is generally applied in aqueous solution because of its great affinity to water. The color of the dye is contributed mainly by a chromophore group present in its chemical structure and is used in textile, paper leather, or food industry. Synthetic dyes are generally made from petroleum by-products and earth minerals. Different types of synthetic dyes used in the textile industry are reactive dyes, azo dyes, etc. Azo dyes are the largest group of synthetic aromatic dye used in the textile industry for dyeing purpose and are highly water soluble in nature. It consist of one or more azo $(-\mathrm{N}=\mathrm{N}-)$ groups and sulfonic $\left(\mathrm{SO}^{3-}\right)$ groups and are of huge commercial interest [2,9]. Generally, azo dyes contain one, two, three, or more azo linkages; linking phenyl, naphthyl rings usually substituted with some functional groups like triazine amine, chloro, hydroxyl, methyl, nitro, and sulfonate [10]. Monoazo dyes contain one nitrogennitrogen bond $(\mathrm{N}=\mathrm{N})$; likewise, diazo dyes contain two $\mathrm{N}=\mathrm{N}$ bonds, triazo dyes contain three $\mathrm{N}=\mathrm{N}$ bonds, and polyazo dyes contain more than three $\mathrm{N}=\mathrm{N}$ bonds.

According to hydrophobicity, azo dyes are mainly of two types: (i) hydrophobic azo dyes that are taken up by bacterial cell and reduced inside the cell and (ii) hydrophilic ones which are reduced outside the bacterial cell. And different azo dyes are widely available for commercial use. Due to nonfluorescent nature of azo dyes, fluorescent probes are used to track its pathway attached with the azo dye by the alkyl bond. In textile azo dyes, synthetic dye, reactive dye, acid dye,
Fig. 1 Different possible methods of synthetic azo dye degradation [7]

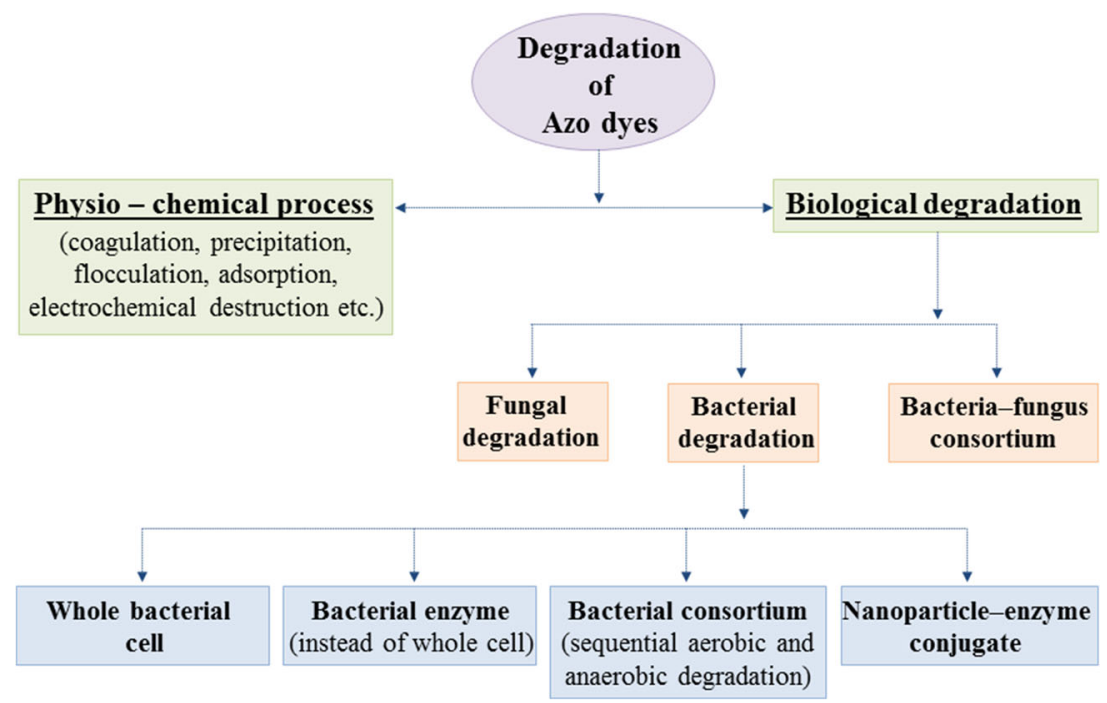


sulfur dye, basic dye, oxidation dye, anthraquinone dye, acridine dye and many other different colorants are used. The main reasons why different types of azo dyes are used in the dying process are its different usage purposes, viz. cellulosic fiber, protein fiber, and synthetic fiber. As all the dyes do not get fixed to the fiber at the time of dying, some percentage of unfixed dyes is released through effluent causing pollution.

\section{Hazardous Effect of Azo Dye on the Environment}

Though the use of dye has been an integral part of the socio-economic component since $2000 \mathrm{BC}$, the use of synthetic dye becomes predominant only after the industrial revolution and becomes an essential part of textile industries [11]. Out of more than 900,000 metric tons of dyes produced annually [12], more than $70 \%$ belongs to the azo group [11, 13]. Many dyes used in textile are only known by their trade name and not their actual chemistry that is the main reason behind causing acute toxic effect where no possible solution to dye degradation can be taken. Textile industries release a huge amount of colored effluent in a surrounding water body without any proper treatment causing major environmental pollution. More industrialization means more use of dyes and more risk of toxicity affecting the entire ecosystem. Owing their xenobiotic and wayward nature, azo dye poses a long-term effect on life. As textile industrial effluent contains a significant amount of dye with many toxic metals, it increases $\mathrm{pH}$, BOD, and COD $[14,15]$ in the water body where it is released. It also disbalances organic-inorganic chemical content of the environment and is affective for the biotic content present in water. When dye gets mixed with water, light penetration efficiency decreased inside the water and complete water ecosystem gets affected. Toxic compounds of azo dye mix with water bodies and enter into fishes or other aquatic animals which are further taken up by human causing hypertension, sporadic disorder, cramps, etc. with prolonged effect. Benzidine-based azo dyes have been recognized as a carcinogen in human urinary bladder and tumorigenic in laboratory animals [2]. It causes hepatocarcinoma, splenic sarcoma, nuclear anomalies in experimental animals, and also chromosomal aberrations in mammalian cells [16]. Due to easy inhalation or its ready solubilization in water, azo dyes cause fast absorption by the skin leading to risk of allergic reaction, cancer, eye irritation, etc. [2]. After the reduction of azo dye, aromatic amine is formed which gets metabolically oxidized to reactive electrophilic species and finally covalently binds to the DNA through an irreversible process (Table 1).

\section{Enzyme-Mediated Degradation of Azo Dyes}

\section{Bacterial Strain Capable of Azo Dye Degradation}

Attempts of identifying the bacteria that may degrade the azo dye has been started back in 1970 with the isolation of three strains, viz. Bacillus subtilis, Aeromonas hydrophila, and Bacillus cereus [17, 18]. The reduction of the azo dye is usually non-specific and decolorization is faster during the bacterial degradation process. A wide range of aerobic and anaerobic bacteria such as Pseudomonas sp., Bacilus subtilis, Geobacillus sp., Escherichia coli, Rhabdobacter sp., Enterococcus sp., Staphylococcus sp., Corneybaterium sp., Lactobacillus sp., Xenophilus sp., Clostridium sp., Acinetobacter sp., Micrococcus sp., Dermacoccus sp., Rhizobium sp., Proteus sp., Morganella sp., Aeromonas sp., Alcaligenes sp., Klebsiellla sp., Shewanella sp., and Alishewanella sp. have been extensively reported for resulting good biodegradation of azo dyes [2, 19-21]. Pseudomonas sp. is widely used in a decolorization study because of its capacity to degrade a variety of azo dyes (Red HE7B, Reactive Blue 172, Reactive Red 22, Reactive Red 2, orange I and II) and is also exploited in degradation of commercial azo dye used in textile wastewaters (Table 2). Some of the aerobic bacterial strains use azo dyes as a sole carbon and nitrogen source in their metabolic pathway, whereas others only reduce the azo group by an oxygen-tolerant enzyme, azoreductase [2].

Broadly bacterial degradation can be classified in two types: using single bacterial strain or using consortia, i.e., mixture of different bacterial strains. A recently isolated strain of Pseudomonas entomophila BS1 collected from surroundings of textile industry has been able to degrade Reactive Black 5 up to $93 \%$ after $120 \mathrm{~h}$ incubation. In high concentration of Reactive Black 5 up to $500 \mathrm{mg} / \mathrm{l}$, the strain has been able to degrade the azo dye [38]. P. rettgeri strain HSL1 and Pseudomonas sp. SUK1 are used as consortia to degrade azo dye like Reactive Black 5, Reactive orange 16, Direct Red 81, and Disperse Red 78. All are completely decolorized under microaerophilic, sequential aerobic/microaerophilic, and microaerophilic/aerobic conditions with some difference in time depending on its chemical structures [8]. Generally, dye-degrading enzymes such as laccase or azoreductase are maximally produced during the early stationary phase of microbial growth. Thus, it is important to clearly understand the growth pattern of a newly isolated microbial strain for optimum enzyme retrieval.

\section{Enzyme-Meditated Decolorization and Degradation of Azo Dye}

Azo dyes are compound with electron deficiency having $(-\mathrm{N}=\mathrm{N}-)$ chromophore group along with many other electron-withdrawing groups. In some cases, generation of 
Table 1 Example of some commonly used textile azo dyes, its application, and primary hazardous effects

\begin{tabular}{|c|c|c|c|}
\hline Types of azo dye & Application & Hazardous effect & References \\
\hline $\begin{array}{l}\text { Benzamine (BZ)-based azo } \\
\text { dye }\end{array}$ & $\begin{array}{l}\text { Proven mutagens and have } \\
\text { been linked to bladder } \\
\text { cancer }\end{array}$ & $\begin{array}{l}\text { According to the National } \\
\text { Institute for Occupational } \\
\text { Safety and Health data, dye } \\
\text { has carcinogenic effect on } \\
\text { human urinary bladder and } \\
\text { tumorigenic effect on variety } \\
\text { of laboratory animals }\end{array}$ & [39] \\
\hline Reactive brilliant red & $\begin{array}{l}\text { Used extensively in textile } \\
\text { due to its attractive color } \\
\text { and fast fixation capacity }\end{array}$ & $\begin{array}{l}\text { Inhibit function of human serum } \\
\text { albumin, may bind to body } \\
\text { protein or enzyme, cause } \\
\text { alteration of function }\end{array}$ & {$[40]$} \\
\hline $\begin{array}{l}\text { Direct Blue } 15 \\
\text { (dimethoxybenzidine-- } \\
\text { based dye) }\end{array}$ & $\begin{array}{l}\text { Substitute for trypan blue, } \\
\text { used in some biological } \\
\text { and staining applications }\end{array}$ & $\begin{array}{l}\text { Mutagenic effect and } \\
\text { mutagenecity causes due to } \\
\text { reduction process, also } \\
\text { having strong carcinogenic } \\
\text { effect }\end{array}$ & {$[2]$} \\
\hline Acid Violet 7 & $\begin{array}{l}\text { Used in food, paper, } \\
\text { cosmetic, and especially } \\
\text { in textile industries }\end{array}$ & $\begin{array}{l}\text { Chromosomal aberration, } \\
\text { acetylcholinesterase activity } \\
\text { inhibition, membrane lipid } \\
\text { peroxidation }\end{array}$ & [41] \\
\hline Malachite Green & $\begin{array}{l}\text { Used as dye staff in silk, } \\
\text { leather, and paper and } \\
\text { controversially used as } \\
\text { antimicrobial in } \\
\text { aquaculture }\end{array}$ & $\begin{array}{l}\text { Carcinogenesis, mutagenesis, } \\
\text { chromosomal fractures, } \\
\text { teratogenecity and respiratory } \\
\text { toxicity. Significant } \\
\text { alterations occur in } \\
\text { biochemical parameters of } \\
\text { blood in MG-exposed fish. } \\
\text { Histopathological effects of } \\
\text { MG include multi-organ tis- } \\
\text { sue injury }\end{array}$ & {$[43]$} \\
\hline $\begin{array}{l}\text { Reactive Black } 5 \\
\text { (sulfonated azo dye) }\end{array}$ & Used as dye staff & $\begin{array}{l}\text { Restrict nitrogen use efficiency } \\
\text { of plant, decrease the urease } \\
\text { activity, chance } \\
\text { mutagenecity, and } \\
\text { carcinogenicity increase }\end{array}$ & $\begin{array}{c}{[17,42,} \\
44]\end{array}$ \\
\hline $\begin{array}{l}\text { Disperse Red } 1 \text { and Disperse } \\
\text { Red } 13\end{array}$ & $\begin{array}{l}\text { Used as textile dye in } \\
\text { industry }\end{array}$ & $\begin{array}{l}\text { Mutagenic to salmonella, } \\
\text { human beings too (first } \\
\text { evaluated using the } \\
\text { micronucleus assay in human } \\
\text { lymphocytes), may affect the } \\
\text { activity and composition of } \\
\text { microbial communities }\end{array}$ & {$[45-47]$} \\
\hline Congo red & Used to dye cotton & $\begin{array}{l}\text { Carcinogenic and mutagenic } \\
\text { effect }\end{array}$ & [48] \\
\hline
\end{tabular}

electron deficiency made the compound less susceptible to the degradation process [15]. But bacteria show an efficient potential in dye degradation with the help of diverse and wellbuild up enzymatic system. The primary step in bacterial decolorization is either aerobic or anaerobic or by sequential method [22], followed by reductive cleavage of the azo bond. Under anaerobic condition, azo dyes are degraded to colorless amine that is carcinogenic in nature [23] and are further degraded by aerobic processes [19]. Sequential microaerophilic or aerobic processes can be used where aromatic amine produced in microaerophilic condition is further degraded in aerobic condition $[15,23,24]$. In case of enzymatic breakdown of industrial azo dyes, mainly two enzymes, viz. azoreductase and laccase [5], seem to have a great potential. Under adverse conditions, peroxidase and oxidase enzymes are involved in other metabolic functions and are also able to degrade the azo dye up to a certain extent (Table 1). These enzymes can act in both extracellular and intracellular ways. Other than bacteria, these enzymes are also reported from fungi, plant, or other sources [5, 14, 25]. Fungi are indeed a great source of dyedegrading enzymes. Microbial enzymes have several advantages compared to other sources because of cheaper culture, maintenance cost, downstream processing, etc.

As enzymes have a wide range of substrate specificity, easy immobilizable in nature and have high efficacy, it can be potentially used in textile effluent treatment. They are also 
Table 2 Bacterial isolates and its specificity to specific dye for degradation and decolorization

\begin{tabular}{|c|c|c|c|}
\hline Name of the bacteria & Isolated form & Dye that degrade & References \\
\hline Pseudomonas spp. & - & Reactive Black, Reactive Blue, Orange I and II & {$[17,38,24]$} \\
\hline Bacillus spp. & - & Acid Red 119, Navy Blue 2GL, Acid Orange 10 & {$[17]$} \\
\hline Bacillus cereus & Soil isolates & Orange II & {$[18]$} \\
\hline Shewanella spp. & Effluents of different dye units & $\begin{array}{l}\text { Reactive Black 5, Direct Red 81, Acid Red 88, Acid } \\
\text { Yellow, } \\
\text { Orange } 3 . \text { Reactive Blue }\end{array}$ & [19] \\
\hline Alishewanella sp. KMK6 & Dye-contaminated soil & $\begin{array}{l}\text { Carmoisine, Golden Yellow HER, Reactive Blue 59, } \\
\text { Red BLI, Chocolate Brown HT }\end{array}$ & {$[20]$} \\
\hline Proteus sp., & - & Congo red & [9] \\
\hline $\begin{array}{l}\text { Mutant Bacillus sp. } \\
\text { (two strains ACT 1, ACT 2) }\end{array}$ & $\begin{array}{l}\text { Tannery effluent, later induced } \\
\text { mutation and selected from that mutated } \\
\text { one }\end{array}$ & Congo red & {$[9,48]$} \\
\hline $\begin{array}{l}\text { Geobacillus } \\
\text { stearothermophilus }\end{array}$ & - & Indigo carmine & {$[50]$} \\
\hline Micrococcus luteus & - & Acid Black & {$[11]$} \\
\hline Aeromonas sp. DH-6 & - & Methyl Orange & {$[51]$} \\
\hline Aeromonas hydrophila & - & Malachite Green, Brilliant Green, Crystal Violet & {$[45]$} \\
\hline Escherichia coli JM 109 & - & Direct Red 71 & {$[45]$} \\
\hline Lysinibacillus sp. AK2 & Dye-contaminated soil sample & Metanil yellow (sulfonated azo dye) & {$[45,49]$} \\
\hline Pseudomonas putida mt-2 & - & Acid Violet 7 & [41] \\
\hline
\end{tabular}

“_” indicates the isolation place of the bacteria that is not reported

substrate specific so they are able to catalyze only the desire reactions, and on the other hand, being biodegradable, it causes minimal environmental pollution. Though enzymes are expensive to produce but it saves energy using lower temperature and pressure. As long as the conditions are controlled, using enzymes in the dye decolorization industry can speed up many reactions and work for a long time after immobilization in suitable matrix. The only concern for the use of enzymes is its temperature sensitivity and the overall usage cost. If waste bioproducts can be used as a media supplement for microbial growth, then the general production cost can be reduced up to a lot.

\section{Mechanism of Degradation and Decolorization by Azoreductase}

Azoreductase (EC 1.7.1.6) [5] is a reducing enzyme that degrade azo dye into colorless amines by means of a reductive cleavage process. It requires low molecular weight reducing equivalent such as FADH or NADH [15] as the electron donor [5] in the form of a redox reaction. On the basis of coenzyme use, this enzyme is of three types: using NADH only, using NADPH only, or using both [5]. Azoreductase can be either cytoplasmic or membrane bound. Microbial azoreductase has great importance for designing the biotreatment process to treat azo dye-containing wastewater [26]. As cytoplasmic azoreductase is not easily diffusible through a cell membrane, thus, contribution of cytoplasmic azoreductase in decolorization has been under doubt because of complex chemistry of some commercial azo dyes [5]. Although certain types of dye do not get degraded efficiently, still, the use of enzymes is advantageous according to substrate specificity and may be efficiently used in textile water pretreatment.

The enzyme cleaves azo bond $(-\mathrm{N}=\mathrm{N}-)$ and transfers four electrons as reducing equivalent. In each stage, two electrons transfer to the azo dye that acts as an electron acceptor and causes decolorization by forming a colorless solution. Resulting intermediate is toxic aromatic amine which is later degraded by the aerobic process [4] or sometimes microaerophilically. Under anaerobic condition, cell membranebound azoreductase uses a redox mediator as an electron shuttle (Fig. 2). The mediators are normally metabolic results of certain substrate used by organisms, such as anthraquinonesulfonates $[5,27]$. This redox mediator-dependent mechanism of membrane-bound azoreductase is different from the mechanism of cytoplasmic azoreductase. Non-sulfonated azo dyes are mainly degraded by the soluble cytoplasmic azoreductase [28] entering through the cell membrane. Degradation in anaerobic condition is more efficient than the aerobic one, as azoreductase is an oxygen-sensitive enzyme. Thus, in aerobic condition, enzyme comes in contact to oxygen and redox mediator is reduced instead of the azo dye [5]. Occasionally, under unfavorable environment, some usual cellular enzymes may also get converted into dye-degrading enzymes, for example, at times, flavin reductase from $E$. coli acts as azoreductase [27] 


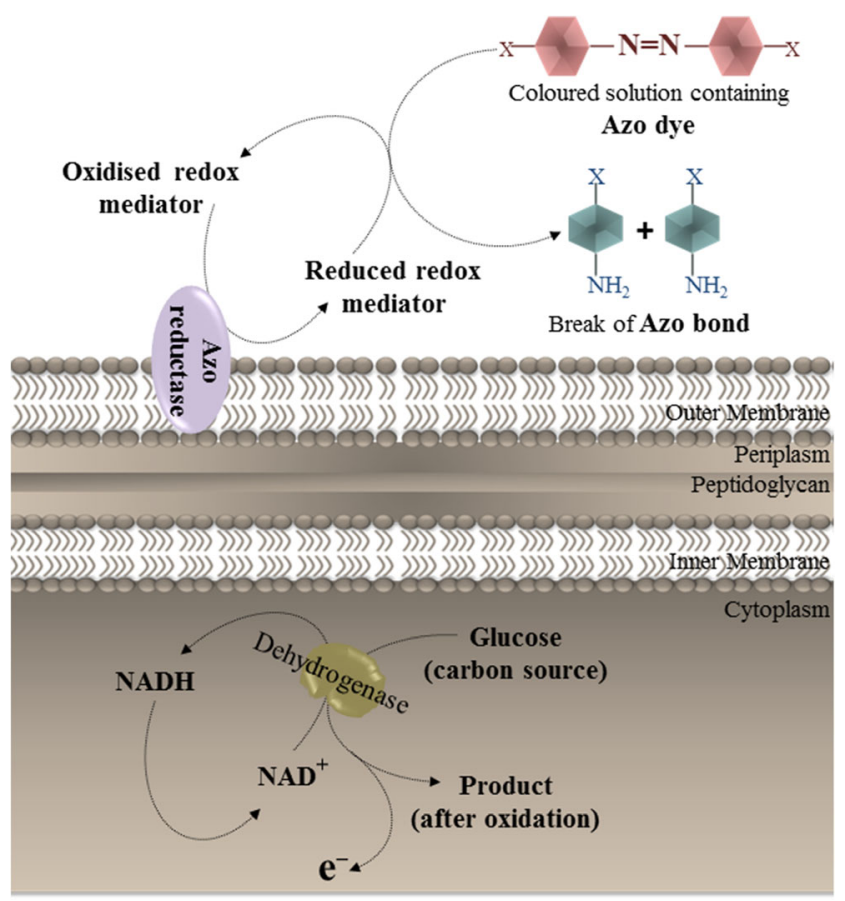

Fig. 2 Mechanism of reduction of azo dyes by azoreductase $[28,36]$

and uses FADH as a redox mediator. As bacteria use azo dye as their sole carbon or nitrogen sources, they can also make product from glucose [29] (Fig. 2).

\section{Mechanism of Degradation and Decolorization by Laccase}

Laccase (EC1.10.3.2) is a low molecular weight multicopper oxidase family enzyme with less substrate specificity and is potent to degrade a wide range of xenobiotic compounds and aromatic and non-aromatic substrates. It has great importance in biotechnological approaches as it has bioremediation capacity and does not use readily available oxygen as an electron acceptor [30]. Several low molecular weight compounds act as the efficient redox mediator in electron transfer steps [31] of laccase reaction. It is able to degrade and decolorize phenolic compound, aromatic azo compounds, etc. It oxidizes the aromatic amine using $\mathrm{Cu}^{2+}$ as the mediator. Majority of laccases are either fungal origin or plant origin and very few have bacterial origin. One disadvantage of fungal laccase is that it is unstable at high temperature and alkaline condition. and for that reason, it is limited in industrial uses [32].

It degrades azo dye using a highly non-specific free radicalmediated mechanism and forms a phenolic compound instead of a toxic aromatic compound $[2,5]$. The enzyme oxidizes the phenolic ring using one electron to generate a phenoxy radical which is again oxidized by the enzyme to produce carbonium ion. 4-Sulfophenyldiazene and benzoquinone get produced by the nucleophilic attack of water, which are unstable in the presence of oxygen. Thus, under aerobic condition, 4-

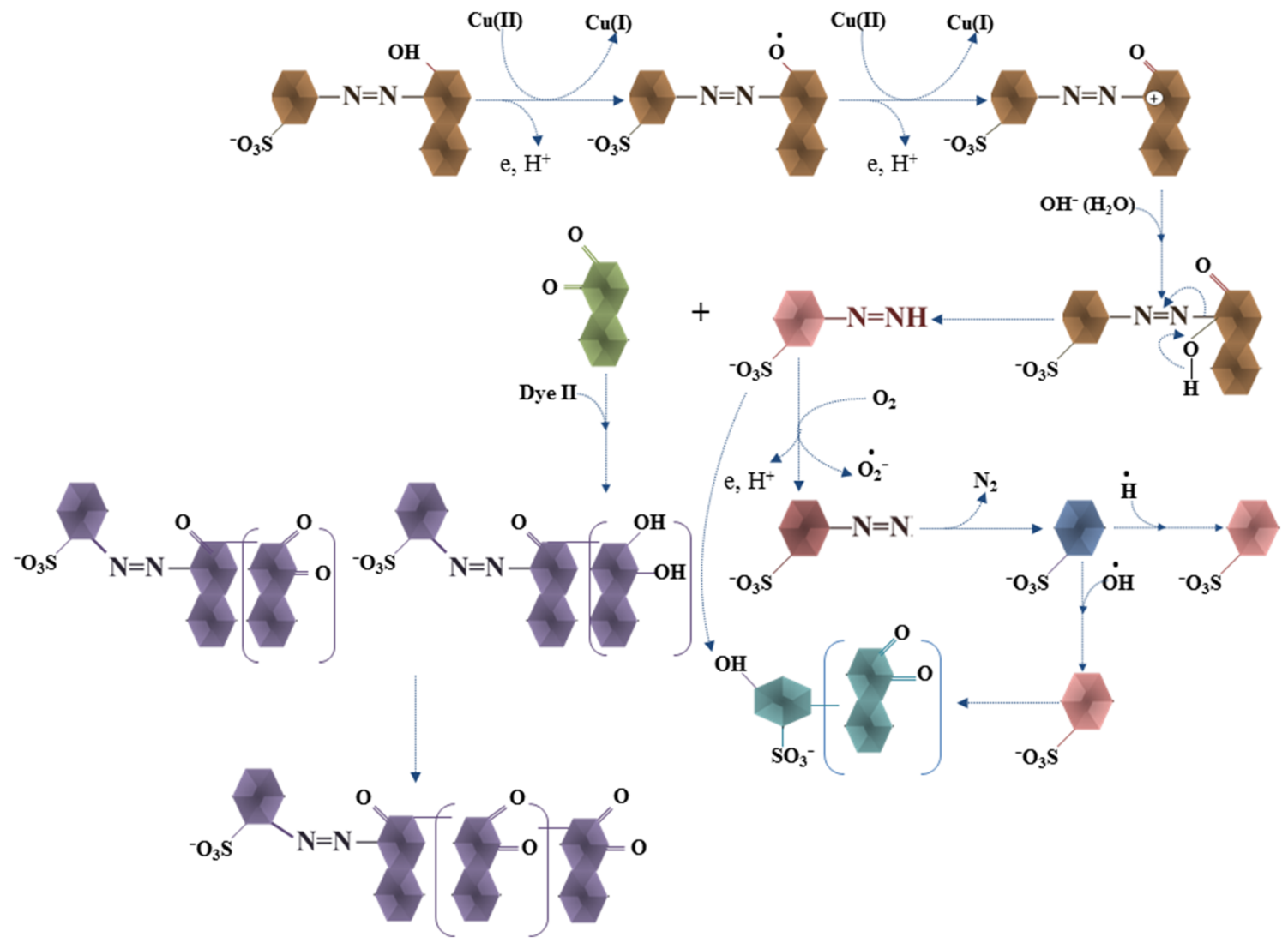

Fig. 3 Proposed mechanism of laccase in degradation of an azo compound, 3-(2-hydroxy-1-naphthylazo) benzenesulfonic acid [28, 37] 


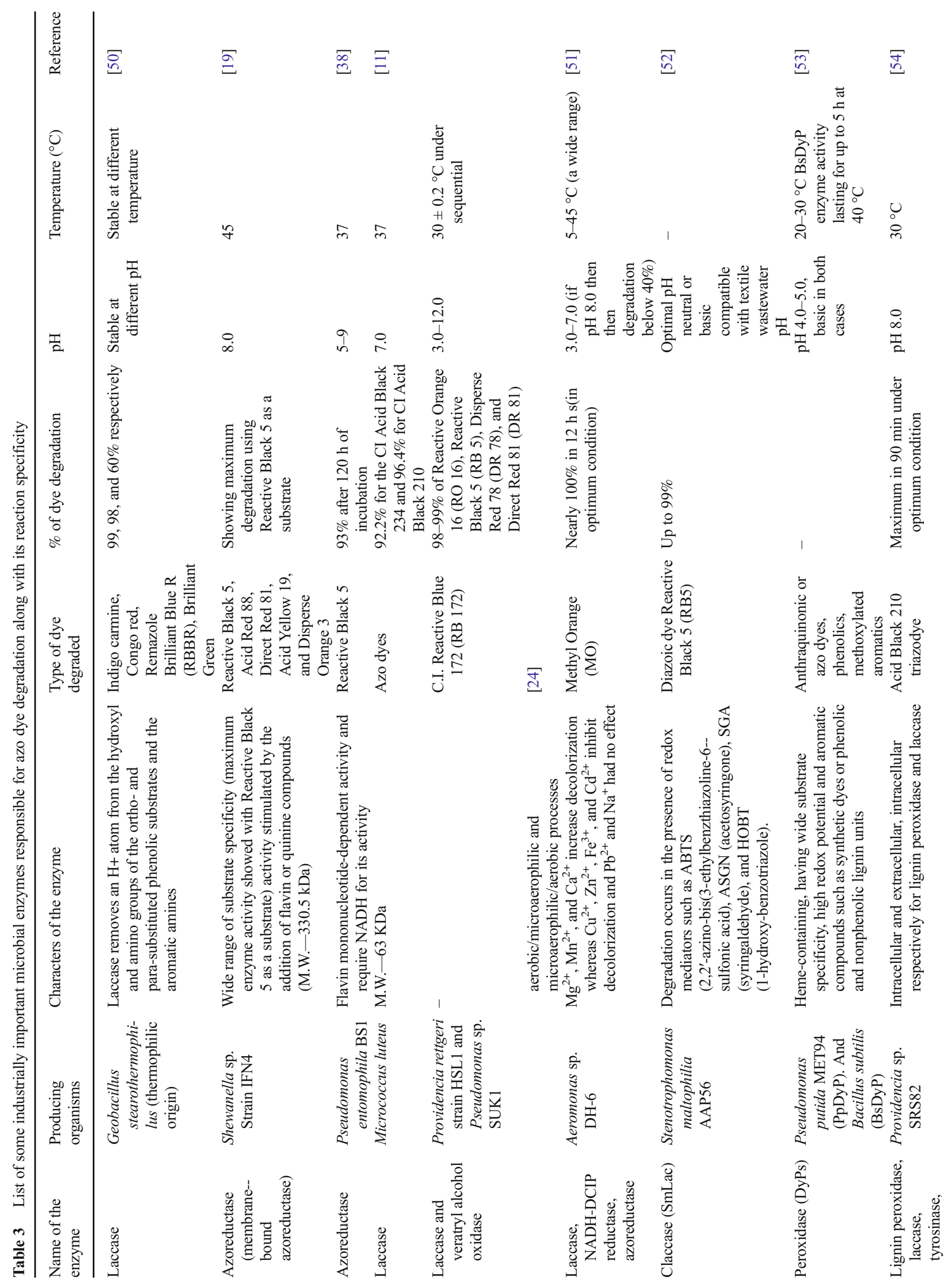




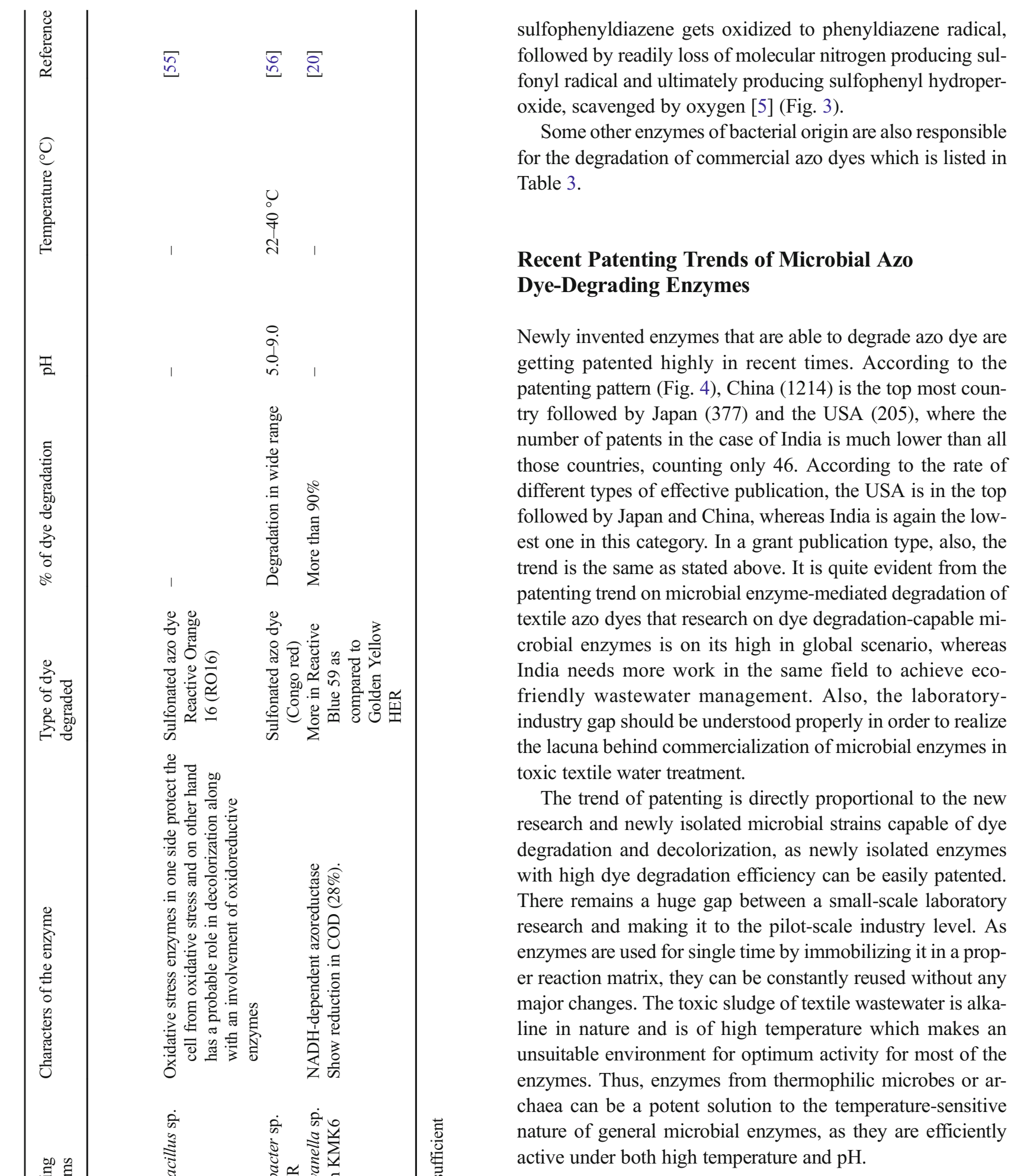

\section{Conclusion}

Due to the chemical complexity of colored waste for presence of many toxic metals, organic chemicals, and synthetic reactive dyes, it leads to acute environmental issue. Mixture of aerobic and anaerobic bacteria or consortia instead of one 


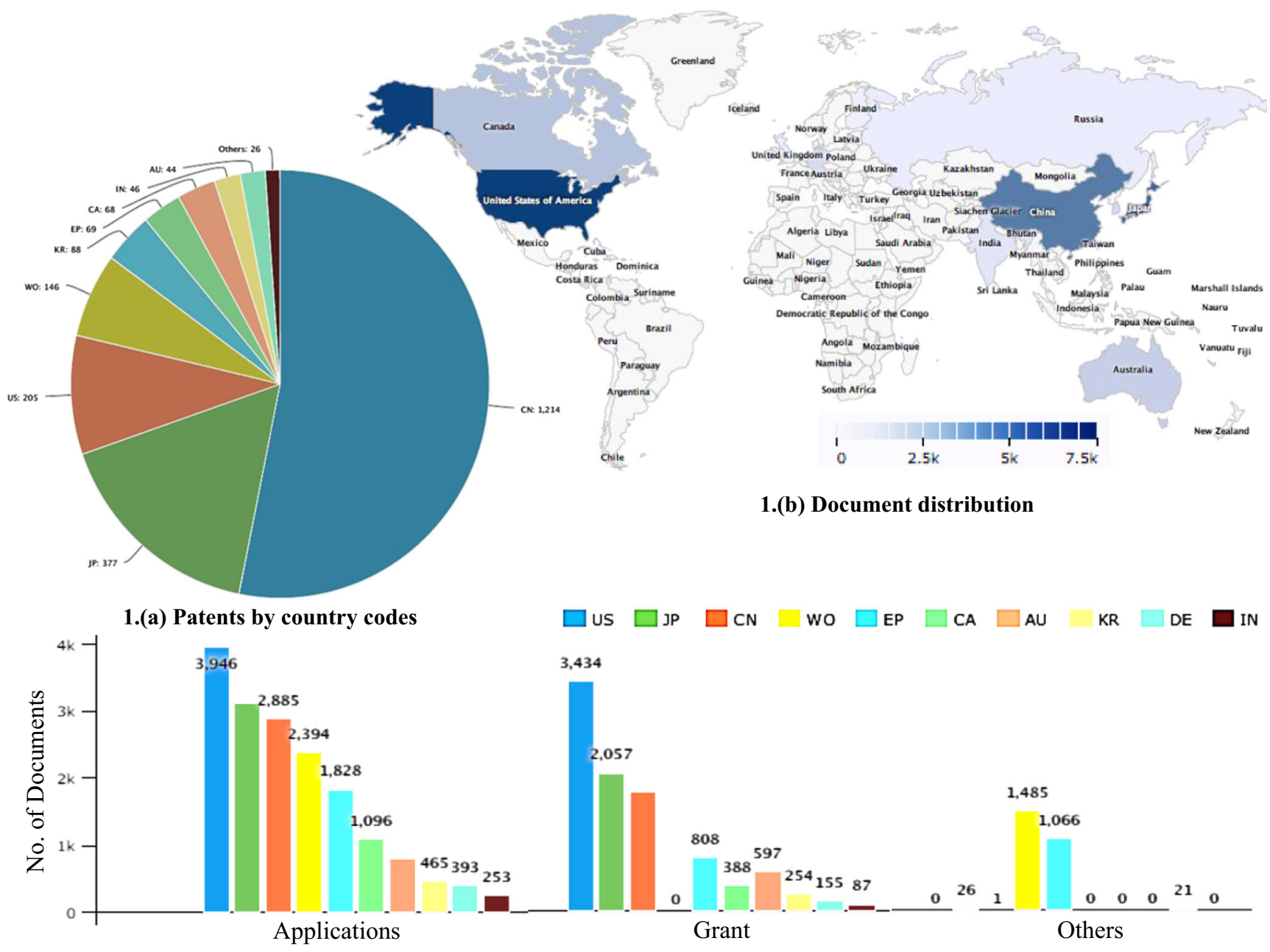

1.(c) Top Countries by Publication type

Fig. 4 Patenting trend of microbial origin dye-degrading enzymes by Relecura, an online patent analysis tool. a Number of patents done by the countries indicated by different colors, where China is the country containing most number of patents worldwide. $\mathbf{b}$ Distribution of patents

single bacterial strain is more effective and efficient to degrade the azo dye. In a consortial system consisting of a mixture of defined microbial population, a large variety of enzymes get released and attack the same chemical structure in different ways, resulting in faster degradation of the complex chemical structure.

Recent trend for azo dye degradation is observing a paradigm shift by invention of nanoparticle-enzyme conjugate that makes the microbial enzyme more substrate specific. Some chemically stabilized nanoparticles are also used to degrade the azo dye very efficiently [33]. Recently, titanium nanoparticle-immobilized fungal laccase (commercially available as DeniLite II $\mathrm{S}$, a laccase produced by submerged fermentation from genetically modified Aspergillus) is used to degrade azo dye-containing toxic textile water. It takes minimum time and removes the color optimally in a critical $\mathrm{pH}$ and temperature [34]. Using this same concept, other enzymenanoparticle conjugates can also be used to degrade azo dye- globally. c Types of patent publications, where in the first part, applicative documents are plotted; in the second part, granted documents of applicative patents are plotted; and in the last part, other patent publication types are plotted

containing toxic textile wastewater. Phenol red degradation process using Catharanthus roseus-mediated zinc oxide nanoparticles has showed efficient dye degradation optimally within $8 \mathrm{~h} \mathrm{[35].} \mathrm{Thus,} \mathrm{enzymatic} \mathrm{degradation} \mathrm{may} \mathrm{be} \mathrm{considered} \mathrm{as}$ an excellent molecular weapon to fight against the deadly issue of environmental pollution from toxic textile sludge. It has a significant potential to address the difficulties of industrial wastewater treatment due to their eco-friendly, inexpensive, and less sludge producing nature.

Acknowledgements Authors are thankful to UGC-Center of Advanced Study, Department of Botany, the University of Burdwan, for pursuing research activities. They are also thankful to an online tool Relecura for the patent analysis. Aparna Banerjee is also thankful to SRF (State Funded) for the financial assistance [Fc (Sc.) /RS/SF/BOT./2014-15/ 103 (3)]. Urmi Halder is thankful to JRF (State Fund) for the financial assistance [Fc (Sc.)/RS/SF/BOT./2017-18/22]. Raju Biswas is thankful to CSIR for the financial assistance as JRF [File No:09/025(0216)/2015EMR-I]. 


\section{References}

1. Tomkin, Robert (2002) Trade promotion authority: CQ house action report

2. Sudha M, Saranya A, Selvakumar G et al (2014) Microbial degradation of azo dyes: a review. Int J Curr Microbiol App Sci 3(2): 670-690

3. Baban A, Yediler A, Lienert D et al (2003) Ozonation of high strength segregated effluents from a woollen textile dyeing and finishing plant. Dyes Pigments 58(2):93-98

4. Pandey A, Singh P, Iyengar L (2007) Bacterial decolorization and degradation of azo dyes. International Biodeterioration \& Biodegradation 59(2):73-84

5. Singh RL, Singh PK, Singh RP (2015) Enzymatic decolorization and degradation of azo dyes - a review. International Biodeterioration \& Biodegradation 104:21-31

6. Singh RL, Khanna SK, Singh GB (1988) Acute and short-term toxicity of a popular blend of metanil yellow and orange II in albino rats. Indian J Exp Biol 26(2):105

7. Saratale RG, Saratale GD, Chang JS et al (2011) Bacterial decolorization and degradation of azo dyes: a review. J Taiwan Inst Chem Eng 42(1):138-157

8. Lade H, Kadam A, Paul D et al (2015) Biodegradation and detoxification of textile azo dyes by bacterial consortium under sequential microaerophilic/aerobic processes. EXCLI Journal Experimental and Clinical Science 14:158

9. Barragán BE, Costa C, Marquez MC (2007) Biodegradation of azo dyes by bacteria inoculated on solid media. Dyes Pigments 75(1): 73-81

10. Bell J, Plumb JJ, Buckley CA et al (2000) Treatment and decolorization of dyes in an anaerobic baffled reactor. J Environ Eng 126(11):1026-1032

11. Kanagaraj J, Senthilvelan T, Panda RC (2015) Degradation of azo dyes by laccase: biological method to reduce pollution load in dye wastewater. Clean Techn Environ Policy 17(6):1443-1456

12. Carmen Z, Daniela S (2012) Textile organic dyes - characteristics, polluting effects and separation/elimination procedures from industrial effluents - a critical overview. In Tech:Croatia. Organic pollutants ten years after the stockholm convention - environmental and analytical update pp. $55-81$

13. Balapure K, Bhatt N, Madamwar D (2015) Mineralization of reactive azo dyes present in simulated textile waste water using down flow microaerophilic fixed film bioreactor. Bioresour Technol 175: $1-7$

14. Sen SK, Raut S, Bandyopadhyay P et al (2016) Fungal decolouration and degradation of azo dyes: a review. Fungal Biology Reviews 30(3):112-133

15. Solís M, Solís A, Pérez HI et al (2012) Microbial decolouration of azo dyes: a review. Process Biochem 47(12):1723-1748

16. Puvaneswari N, Muthukrishnan J, Gunasekaran P (2006) Toxicity assessment and microbial degradation of azo dyes 44(8):618-626

17. Dave SR, Patel TL, Tipre DR (2015) Bacterial degradation of azo dye containing wastes. In: Springer International Publishing. Microbial degradation of synthetic dyes in wastewaters, pp 57-83

18. Wuhrmann K, Mechsner KL, Kappeler TH (1980) Investigation on rate - determining factors in the microbial reduction of azo dyes. Appl Microbiol Biotechnol 9(4):325-338

19. Imran M, Negm F, Hussain S et al (2016) Characterization and purification of membrane-bound azoreductase from azo dye degrading Shewanella sp. strain IFN4. CLEAN-Soil, Air, Water 44(11):1523-1530

20. Kolekar YM, Konde PD, Markad VL et al (2013) Effective bioremoval and detoxification of textile dye mixture by Alishewanella sp. KMK6. Appl Microbiol Biotechnol 97(2):881889
21. Haghshenas H, Kay M, Dehghanian F et al (2016) Molecular dynamics study of biodegradation of azo dyes via their interactions with AzrC azoreductase. J Biomol Struct Dyn 34(3):453-462

22. Popli S, Patel UD (2015) Destruction of azo dyes by anaerobicaerobic sequential biological treatment: a review. Int J Environ Sci Technol 12(1):405-420

23. Stolz A (2001) Basic and applied aspects in the microbial degradation of azo dyes. Appl Microbiol Biotechnol 56(1):69-80

24. Lade H, Kadam A, Paul D et al (2015) Biodegradation and detoxification of textile azo dyes by bacterial consortium under sequential microaerophilic/aerobic processes. EXCLI J 14:158

25. McMullan G, Meehan C, Conneely A et al (2001) Microbial decolourisation and degradation of textile dyes. Appl Microbiol Biotechnol 56(1):81-87

26. Zimmermann T, Kulla HG, Leisinger T (1982) Properties of purified Orange II azoreductase, the enzyme initiating azo dye degradation by Pseudomonas KF46. Eur J Biochem 129(1):197-203

27. Russ R, Rau J, Stolz A (2000) The function of cytoplasmic flavin reductases in the reduction of azo dyes by bacteria. Appl Environ Microbiol 66(4):1429-1434

28. Chacko JT, Subramaniam K (2011) Enzymatic degradation of azo dyes - a review. Int J Environ Sci 1(6):1250

29. Lima DR, Baeta BE, Silva GAD et al (2014) Use of multivariate experimental designs for optimizing the reductive degradation of an azo dye in the presence of redox mediators. Química Nova 37(5): $827-832$

30. Kalyani D, Dhiman SS, Kim H et al (2012) Characterization of a novel laccase from the isolated Coltricia perennis and its application to detoxification of biomass. Process Biochem 47(4):671-678

31. Wong Y, Yu J (1999) Laccase-catalyzed decolorization of synthetic dyes. Water Res 33(16):3512-3520

32. Guan ZB, Song CM, Zhang N et al (2014) Overexpression, characterization, and dye-decolorizing ability of a thermostable, $\mathrm{pH}$ stable, and organic solvent-tolerant laccase from Bacillus pumilus W3. J Mol Catal B Enzym 101:1-6

33. Sha Y, Mathew I, Cui Q et al (2016) Rapid degradation of azo dye methyl orange using hollow cobalt nanoparticles. Chemosphere 144:1530-1535

34. Mohajershojaei K, Mahmoodi NM, Khosravi A (2015) Immobilization of laccase enzyme onto titania nanoparticle and decolorization of dyes from single and binary systems. Biotechnol Bioprocess Eng 20(1):109-116

35. Kalaiselvi A, Roopan SM, Madhumitha G et al (2016) Catharanthus roseus-mediated zinc oxide nanoparticles against photocatalytic application of phenol red under UV@ 365 nm. Curr Sci 111(11):1811-1815

36. Keck A, Klein J, Kudlich M et al (1997) Reduction of azo dyes by redox mediators originating in the naphthalenesulfonic acid degradation pathway of Sphingomonas sp. strain BN6. Appl Environ Microbiol 63(9):3684-3690

37. Zille A, Górnacka B, Rehorek A et al (2005) Degradation of azo dyes by Trametes villosa laccase over long periods of oxidative conditions. Appl Environ Microbiol 71(11):6711-6718

38. Khan S, Abdul M (2015) Degradation of Reactive Black 5 dye by a newly isolated bacterium Pseudomonas entomophila BS1. Can J Microbiol 62(3):220-232

39. Manning BW, Cerniglia CE, Federle TW (1985) Metabolism of the benzidine-based azo dye Direct Black 38 by human intestinal microbiota. Appl Environ Microbiol 50(1):10-15

40. Li WY, Chen FF, Wang SL (2010) Binding of reactive brilliant red to human serum albumin: insights into the molecular toxicity of sulfonic azo dyes. Protein and peptide letters 17(5):621-629

41. Mansour HB, Ayed-Ajmi Y, Mosrati R et al (2010) Acid violet 7 and its biodegradation products induce chromosome aberrations, lipid peroxidation, and cholinesterase inhibition in mouse bone marrow. Environ Sci Pollut Res 17(7):1371-1378 
42. Topaç FO, Dindar E, Uçaroğlu S et al (2009) Effect of a sulfonated azo dye and sulfanilic acid on nitrogen transformation processes in soil. J Hazard Mater 170(2):1006-1013

43. Srivastava S, Sinha R, Roy D (2004) Toxicological effects of malachite green. Aquat Toxicol 66(3):319-329

44. Gottlieb A, Shaw C, Smith A et al (2003) The toxicity of textile reactive azo dyes after hydrolysis and decolourisation. J Biotechnol 101(1):49-56

45. Mahmood S, Azeem K, Muhammad A et al (2016) Detoxification of azo dyes by bacterial oxidoreductase enzymes. Crit Rev Biotechnol 36(4):639-651

46. Chequer FMD, Lizier TM, De Felício R et al (2015) The azo dye Disperse Red 13 and its oxidation and reduction products showed mutagenic potential. Toxicol in Vitro 29(7):1906-1915

47. Ferraz ERA, Umbuzeiro GA, de Almeida G et al (2011) Differential toxicity of Disperse Red 1 and Disperse Red 13 in the Ames test, HepG2 cytotoxicity assay, and Daphnia acute toxicity test. Environ Toxicol 26(5):489-497

48. Gopinath KP, Murugesan S, Abraham J et al (2009) Bacillus sp. mutant for improved biodegradation of Congo red: random mutagenesis approach. Bioresour Technol 100(24):6295-6300

49. Anjaneya O, Souche SY, Santoshkumar M et al (2011) Decolorization of sulfonated azo dye metanil yellow by newly isolated bacterial strains: Bacillus sp. strain AK1 and Lysinibacillus sp. strain AK2. J Hazard Mater 190(1):351-358
50. Mehta R, Singhal P, Singh H et al (2016) Insight into thermophiles and their wide-spectrum applications. 3 Biotech 6(1):1-9

51. Du LN, Li G, Zhao YH et al (2015) Efficient metabolism of the azo dye methyl orange by Aeromonas sp. strain DH-6: characteristics and partial mechanism. International Biodeterioration \& Biodegradation 105:66-72

52. Galai S, Korri-Youssoufi H, Marzouki MN (2014) Characterization of yellow bacterial laccase SmLac/role of redox mediators in azo dye decolorization. J Chem Technol Biotechnol 89(11):1741-1750

53. Santos A, Mendes S, Brissos V et al (2014) New dye-decolorizing peroxidases from Bacillus subtilis and Pseudomonas putida MET94: towards biotechnological applications. Appl Microbiol Biotechnol 98(5):2053-2065

54. Agrawal S, Tipre D, Patel B et al (2014) Optimization of triazo Acid Black 210 dye degradation by Providencia sp. SRS82 and elucidation of degradation pathway. Process Biochem 49(1):110-119

55. Bedekar PA, Saratale RG, Saratale GD et al (2014) Oxidative stress response in dye degrading bacterium Lysinibacillus sp. RGS exposed to Reactive Orange 16, degradation of $\mathrm{RO}_{16}$ and evaluation of toxicity. Environ Sci Pollut Res 21(18):11075-11085

56. Prasad SS, Aikat K (2014) Study of bio-degradation and biodecolourization of azo dye by Enterobacter sp. SXCR Environmental Technology 35(8):956-965 